\title{
Optimasi Daya Reaktif Untuk Mereduksi Rugi Daya Pada Sistem Kelistrikan Area Bangka Menggunakan Metode Algoritma Genetika
}

\author{
Muhammad Iqbal $^{1}$,Wahri Sunanda ${ }^{1}$ \\ ${ }^{1)}$ Jurusan Teknik Elektro, Fakultas Teknik, Universitas Bangka Belitung \\ e-mail : muhammad102elektro@gmail.com
}

\begin{abstract}
Abstrak
Pada suatu sistem tenaga listrik salah satu faktor yang mempengaruhi rugi -rugi daya saluran adalah ketersedian daya reaktif dalam sistem. Kebutuhan daya reaktif dalam sistem menentukan nilai profil tegangan bus. Untuk mengurangi rug-rugi daya saluran dan meningkatkan profil tegangan sistem diperlukan pengaturan daya reaktif yang tepat dengan memperhitungkan lokasi penempatan dan besarnya nilai kapasitor.Pengaturan daya reaktif dapat lebih mudah dilakukan apabila pada suatu bus terdapat sumber pembangkit daya reaktif seperti kapasitor. Dengan menggunakan algoritma genetika pengaturan daya reaktif yang tepat dapat dilakukan dengan optimasi penempatan kapasitor dan nilai kapasitor pada sistem tenaga listrik. Pada pengujian optimasi daya reaktif sistem kelistrikan area Bangka tanggal 28 Maret 2017 diperoleh rugi-rugi daya saluran sebelum optimasi sebesar 0,195 MW dan 0,543 MVAr, sedangkan rugi daya sesudah optimasi sebesar 0,177 MW dan 0,502 MVAr. Penurunan rugi daya saluran sebesar 0,018 MW dan 0,041MVAr atau sebesar 9,23 \% untuk daya aktif dan 7,55 \% untuk daya reaktif. Parameter algoritma genetika yang terpilih dalam pengujian optimasi daya reaktif adalah Pc $=\mathbf{1 . 0}$ Pm = 0,5 dengan injeksi kapasitor 1-7 MVAr (pengujian B bagian 4).Total injeksi daya reaktif yang diperoleh dari optimasi sebesar 27,93 MVAr.Penempatan kapasitor yang didapat adalah pada bus 2 = 3 MVAr, bus $6=1$ MVAr, bus $9=7$ MVAr, bus $10=6$ MVAr, bus $11=7$ MVAr, bus $12=3$ MVAr, bus 13 $=1$ MVAr.
\end{abstract}

Kata kunci : Daya reaktif, Algoritma genetika, Rugi daya, Optimasi

\section{Abstract}

In a power system one of the factors affecting the channel power losses is the availability of reactive power in the system. Reactive power requirements in the system determine the value of the bus voltage profile. To reduce channel power loss and increase the system voltage profile requires proper reactive power regulation taking into account the location of the placement and the value of the capacitor. Reactive power management can be more easily done when on a bus there is a reactive power generator such as a capacitor. By using genetic algorithms the appropriate reactive power regulation can be done by optimizing capacitor placement and capacitor values in electrical power systems. In the optimum reactive power optimization testing of the Bangka area of electricity system on March 28, 2017 obtained channel power losses before optimization of $0.195 \mathrm{MW}$ and 0.543 MVAr, while power loss after optimization of 0,177MW and 0,502MVAr. Decreased channel power losses of $0,018 \mathrm{MW}$ and $0,041 \mathrm{MVAr}$ or by $9,23 \%$ for active power and $7,55 \%$ for reactive power. The correct genetic algorithm parameter in reactive power optimization is $\mathrm{Pc}=1.0 \mathrm{Pm}=0.5$ with 1-7 MVAr capacitor injection (part B test 4). Total reactive power injection obtained from optimization of 27.93 MVAr. The placement of capacitors obtained is on bus2 $=3$ MVAr, bus $6=1$ MVAr, bus $9=7$ MVAr, bus $10=6$ MVAr, bus $11=7$ MVAr, bus 12 = 3 MVAr, bus 13 = 1 MVAr.

Keywords : Genetic Algorithm, Optimization, Power loss, And Reactive power

\section{PENDAhUluaN}

\subsection{Latar Belakang}

Pada suatu sistem tenaga listrik untuk menghindari rugi daya yang besar dilakukan dengan menaikkan tegangan. Dengan cara menaikkan tegangan maka arus menjadi kecil sehingga rugi daya dapat diminimalkan. Perubahan nilai tegangan pada sistem tenaga listrik dipengaruhi oleh arus penguat generator, daya reaktif beban, daya reaktif yang didapat daalam sistem selain generator seperti dari kondensator dan reaktor dan posisi tap transformator (Djiteng, 2006)

Pengaturan tegangan pada sistem akan lebih mudah apabila di titik tersebut terdapat sumber daya reaktif yang dapat diatur. Dengan adanya pengaturan daya reaktif maka rugi daya dan susut tegangan daat dikurangi, karena tegangan pada suatu sistem memiliki nilai yang berbedabeda di setiap simpul sistem.

Pada kelistrikan di provinsi Kepulauan Bangka Belitung area bangka menggunakan saluran listrik yang di dominasi oleh saluran udara tegangan menengah 20 kV(SUTM). Kelistrikan area bangka memiliki panjang total SUTM $20 \mathrm{kV}$ sebesar $2.360 .293 \mathrm{~km}$, sedangkan untuk saluran kabel tegangan menengah (SKTM) sebesar 49,253 km (Khoirul Fahri,2016). 


\subsection{Langkah Penelitian}

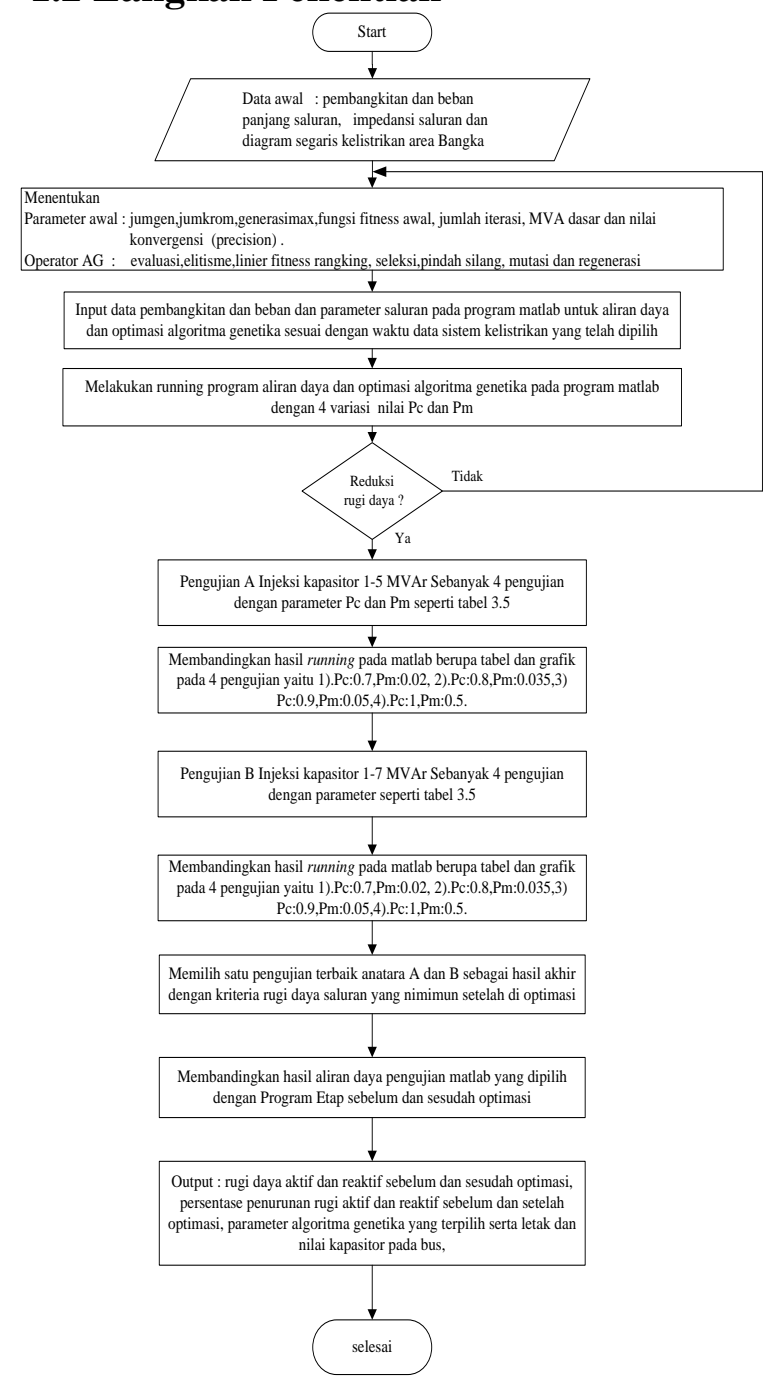

Gambar 1 Flowchart dalam melakukan penelitian

\subsection{Model penelitian yang digunakan}

Model optimasi yang di usulkan dalam penelitin ini adalah :

1. Parameter pada algoritma genetika
a. Jumlah gen
$=13$
b. Probabilitas mutasi (Pm)
$=0,02-0,5$
c. Probabilitas crossover $(\mathrm{Pc})=0,7-1$
d. Jumlah kromosom
$=20$
e. GenerasiMax
$=1000$
f. Maksimal iterasi
$=200$

2. Data sistem
a. Dasar MVA
$=100 \mathrm{MVA}$
b. Dasar kV
$=150 \mathrm{kV}$
c. Swing bus
= bus 1 (MPP Air Anyir)

\section{HASIL DAN PEMBAHASAN}

\subsection{Sistem Kelistrikan Area Bangka}

Berdasarkan kondisi kelistrikan area Bangka memiliki sistem yang terinterkoneksi dan sistem yang terisolir. Adapun sistem interkoneksi dan sistem isolated tersebut adalah sebagai berikut :
1. Sistem Interkoneksi

Terdiri dari PLTU Air Anyir Unit 1 dan unit 2, MPP \#1 dan MPP \#2, PLTD Merawang, PLTU Listrindo, Sewatama, Kertabumi 1 dan Kertabumi 2

2. Sistem Isolated

Terdiri dari PLTD Koba, PLTD Mentok dan PLTD Toboali

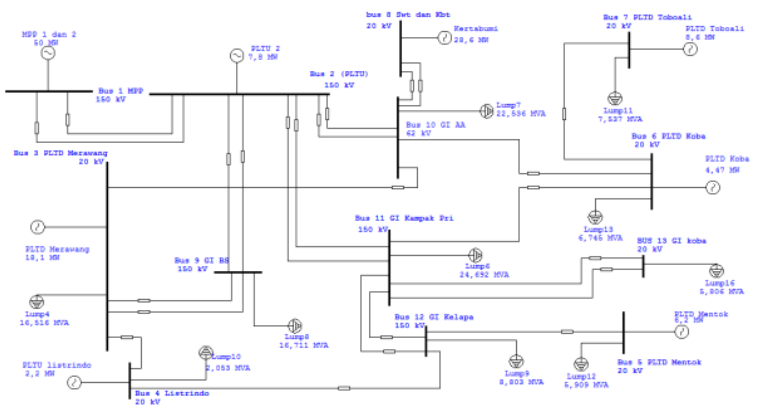

Gambar 2 Diagram segaris kelistrikan area Bangka untuk pengujian

\subsection{Pembagian jenis-jenis bus dalam sistem}

Pada tabel 1 merupakan data bus pada sistem tenaga listrik area Bangka. Adapun hal-hal yang perlu di tentukan sebelum perhitungan aliran daya.

Swing Bus : Bus MPP Air Anyir / Bus 1

Bus Generator : Bus 2,3,4,5,6,7 dan 8

Bus Beban : Bus 9,10,11,12 dan 13

Tabel 1 Data nama dan tipe setiap bus sistem kelistrikan area Bangka

\begin{tabular}{cll}
\hline No.Bus & \multicolumn{1}{c}{ Nama Bus } & \multicolumn{1}{c}{ Tipe Bus } \\
\hline 1 & MPP Air Anyir & Slack/swing \\
\hline 2 & PLTU Air Anyir & PV/Bus Generator \\
\hline 3 & PLTD Merawang & PV/Bus Generator \\
\hline 4 & PLTU Listrindo & PV/Bus Generator \\
\hline 5 & PLTD Mentok & PV/Bus Generator \\
\hline 6 & PLTD Koba & PV/Bus Generator \\
\hline 7 & PLTD Toboali & PV/Bus Generator \\
\hline 8 & $\begin{array}{l}\text { PLTD Sewatama dan } \\
\text { kertabumi }\end{array}$ & PV/Bus Generator \\
\hline 9 & GI Bukit semut & PQ/Bus Beban \\
\hline 10 & GI Air Anyir & PQ/Bus Beban \\
\hline 11 & GI Kampak & PQ/Bus Beban \\
\hline 12 & GI Kelapa & PQ/Bus Beban \\
\hline 13 & GI Koba & PQ/Bus Beban \\
\hline & &
\end{tabular}

\subsection{Data rating kapasitor bank}

Pada pengujian yang dilakukan rating kapasitor yang akan digunakan terdiri dari tiga nilai yang memiliki injeksi MVAr sebagai berikut :

1. Injeksi MVAr dari $1-5 \mathrm{MVAr}$

2. Injeksi MVAr dari 1-7 MVAr

Kedua nilai injeksi tersebut akan dilakukan pengujian satu per satu dan setiap satu kali pengujian terdapat 4 variasi nilai probabilitas crossover (pc) dan probabilitas mutasi (pm) dengan banyaknya running minimal 4 kali. 
3.4 Hasil pengujian terbaik

1. Pengujian empat $B$ dengan

$P m=0,5$ dan $P c=1$

a. Aliran daya sebelum optimasi

Tabel 2 Hasil perhitungan aliran daya sebelum penambahan bank kapasitor

\begin{tabular}{|c|c|c|c|c|c|c|c|}
\hline \multirow{2}{*}{$\begin{array}{l}\text { No. } \\
\text { Bus }\end{array}$} & \multicolumn{2}{|c|}{ Pembangkit } & \multicolumn{2}{|c|}{ Beban } & \multirow{2}{*}{$\mathbf{V}(\mathbf{p u})$} & \multirow{2}{*}{ Sudut $\left({ }^{\circ}\right)$} & \multirow{2}{*}{$\begin{array}{c}\text { Faktor } \\
\text { daya }\end{array}$} \\
\hline & $\mathbf{P}(\mathbf{M W})$ & Q(MVAr) & $\mathbf{P}(\mathbf{M W})$ & Q(MVAr) & & & \\
\hline 1 & 27,89 & $-8,27$ & 0 & 0 & 1,000 & 0,000 & 0,959 \\
\hline 2 & 7,80 & 22,66 & 0 & 0 & 1,000 & $-0,028$ & 0,325 \\
\hline 3 & 18,10 & 15,51 & 14,58 & 7,67 & 1,000 & $-0,363$ & 0,409 \\
\hline 4 & 2,20 & 2,37 & 1,82 & 0,95 & 1,000 & $-0,746$ & 0,258 \\
\hline 5 & 6,20 & 4,56 & 5,23 & 2,75 & 1,000 & $-0,992$ & 0,473 \\
\hline 6 & 4,47 & 6,21 & 5,76 & 3,03 & 1,000 & $-0,327$ & 0,376 \\
\hline 7 & 8,60 & 1,91 & 6,76 & 3,51 & 1,000 & $-0,029$ & 0,755 \\
\hline 8 & 28,60 & $-1,76$ & 0 & 0 & 1,000 & $-0,016$ & 0,998 \\
\hline 9 & 0,00 & 0,00 & 14,79 & 7,78 & 0,998 & $-0,424$ & 0,885 \\
\hline 10 & 0,00 & 0,00 & 19,94 & 10,5 & 1,000 & $-0,026$ & 0,885 \\
\hline 11 & 0,00 & 0,00 & 21,85 & 11,5 & 0,996 & $-0,434$ & 0,885 \\
\hline 12 & 0,00 & 0,00 & 7,79 & 4,1 & 0,995 & $-0,947$ & 0,885 \\
\hline 13 & 0,00 & 0,00 & 5,14 & 2,7 & 0,989 & $-1,117$ & 0,885 \\
\hline \multicolumn{6}{|c|}{ Total Pembangkitan (MW+jMVAr) } & 103,86 & 43,20 \\
\hline \multicolumn{6}{|c|}{ Total Pembebanan (MW+jMVAr) } & 103,66 & $\mathbf{5 4 , 4 9}$ \\
\hline \multicolumn{6}{|c|}{ Total Rugi-Rugi Saluran (MW+jMVAr) } & 0,195 & 0,543 \\
\hline
\end{tabular}

\section{b. Aliran daya sesudah optimasi}

Tabel 3 Hasil perhitungan aliran daya sesudah

\begin{tabular}{|c|c|c|c|c|c|c|c|c|}
\hline \multirow{2}{*}{$\begin{array}{c}\text { No. } \\
\text { Bu } \\
\text { s }\end{array}$} & \multicolumn{2}{|c|}{ Pembangkit } & \multicolumn{2}{|c|}{ Beban } & \multirow[b]{2}{*}{$\mathrm{V}(\mathrm{pu})$} & \multirow[b]{2}{*}{$\begin{array}{l}\text { Sudut } \\
\left(^{\circ}\right)\end{array}$} & \multirow[b]{2}{*}{ Pf } & \multirow{2}{*}{$\begin{array}{c}\text { Inje } \\
\text { ksi } \\
\text { Q }\end{array}$} \\
\hline & $\mathbf{P}(\mathbf{M W})$ & $\begin{array}{l}\text { Q(MVAr } \\
\text { ) }\end{array}$ & $\mathbf{P}(\mathbf{M W})$ & $\underset{r}{\mathrm{Q}(\mathrm{MVA}}$ & & & & \\
\hline 1 & 27,87 & $-8,26$ & 0 & 0 & 1,000 & 0,000 & 0,959 & 0 \\
\hline 2 & 7,80 & 8,02 & 0 & 0 & 1,000 & $-0,028$ & 0,578 & 3 \\
\hline 3 & 18,10 & 10,24 & 14,58 & 7,67 & 1,000 & $-0,359$ & 0,808 & 0 \\
\hline 4 & 2,20 & 1,10 & 1,82 & 0,95 & 1,000 & $-0,723$ & 0,928 & 0 \\
\hline 5 & 6,20 & 3,15 & 5,23 & 2,75 & 1,000 & $-0,952$ & 0,926 & 0 \\
\hline 6 & 4,47 & 3,75 & 5,76 & 3,03 & 1,000 & $-0,307$ & 0,600 & 1 \\
\hline 7 & 8,60 & 1,91 & 6,76 & 3,51 & 1,000 & $-0,009$ & 0,755 & 0 \\
\hline 8 & 28,60 & $-4,71$ & 0 & 0 & 1,000 & $-0,016$ & 0,987 & 0 \\
\hline 9 & 0,00 & 0,00 & 14,79 & 7,78 & 0,999 & $-0,444$ & 0,999 & 7 \\
\hline 10 & 0,00 & 0,00 & 19,94 & 10,5 & 1,000 & $-0,027$ & 0,975 & 6 \\
\hline 11 & 0,00 & 0,00 & 21,85 & 11,5 & 0,998 & $-0,468$ & 0,979 & 7 \\
\hline 12 & 0,00 & 0,00 & 7,79 & 4,1 & 0,998 & $-1,001$ & 0,990 & 3 \\
\hline 13 & 0,00 & 0,00 & 5,14 & 2,7 & 0,993 & $-1,188$ & 0,949 & 1 \\
\hline \multicolumn{7}{|c|}{ Total Pembangkitan (MW+jMVAr) } & 103,84 & $\begin{array}{c}15,2 \\
0\end{array}$ \\
\hline \multicolumn{7}{|c|}{ Total Pembebanan $(M W+j M V A r)$} & 103,66 & $\begin{array}{c}54,4 \\
9\end{array}$ \\
\hline \multicolumn{7}{|c|}{ Total Rugi-Rugi Saluran (MW+jMVAr) } & 0,177 & 0,50 \\
\hline \multicolumn{7}{|c|}{ Total Injeksi Daya reaktif (jMVAr) } & \multicolumn{2}{|c|}{27,93} \\
\hline
\end{tabular}

\section{c. Perbandingan rugi daya saluran sebelum dan sesudah optimasi}

Tabel 4 Rugi-rugi saluran sebelum dan sesudah penambahan bank kapasitor

\begin{tabular}{|c|c|c|c|c|c|c|c|c|}
\hline \multirow{3}{*}{ No } & \multirow{3}{*}{$\begin{array}{l}\text { Dari } \\
\text { Bus }\end{array}$} & \multirow{3}{*}{$\begin{array}{l}\text { Ke } \\
\text { Bus }\end{array}$} & \multicolumn{6}{|c|}{ Losses } \\
\hline & & & \multicolumn{2}{|c|}{ MW } & \multicolumn{4}{|c|}{ MVAr } \\
\hline & & & $\begin{array}{c}\text { Sebelu } \\
\text { m }\end{array}$ & Sesudah & Turun & Sebelum & $\begin{array}{c}\text { Sesud } \\
\text { ah }\end{array}$ & Turun \\
\hline 1 & 1 & 2 & 0,004 & 0,004 & 0,000 & 0,014 & 0,014 & 0,000 \\
\hline 2 & 2 & 9 & 0,018 & 0,018 & 0,000 & 0,061 & 0,059 & 0,002 \\
\hline 3 & 2 & 10 & 0,000 & 0,000 & 0,000 & 0,000 & 0,000 & 0,000 \\
\hline 4 & 2 & 11 & 0,070 & 0,067 & 0,003 & 0,236 & 0,227 & 0,009 \\
\hline 5 & 3 & 4 & 0,009 & 0,007 & 0,002 & 0,013 & 0,011 & 0,002 \\
\hline 6 & 3 & 9 & 0,007 & 0,007 & 0,000 & 0,022 & 0,022 & 0,000 \\
\hline 7 & 3 & 10 & 0,018 & 0,017 & 0,001 & 0,027 & 0,026 & 0,001 \\
\hline 8 & 4 & 12 & 0,009 & 0,009 & 0,000 & 0,013 & 0,013 & 0,000 \\
\hline 9 & 5 & 12 & 0,007 & 0,001 & 0,006 & 0,010 & 0,002 & 0,008 \\
\hline 10 & 6 & 7 & 0,006 & 0,006 & 0,000 & 0,010 & 0,010 & 0,000 \\
\hline 11 & 8 & 10 & 0,002 & 0,002 & 0,000 & 0,005 & 0,005 & 0,000 \\
\hline 12 & 10 & 6 & 0,007 & 0,006 & 0,001 & 0,011 & 0,010 & 0,001 \\
\hline 13 & 11 & 6 & 0,008 & 0,005 & 0,003 & 0,012 & 0,008 & 0,004 \\
\hline 14 & 11 & 12 & 0,012 & 0,017 & $-0,005$ & 0,039 & 0,056 & $-0,017$ \\
\hline 15 & 11 & 13 & 0,021 & 0,025 & $-0,004$ & 0,070 & 0,084 & $-0,014$ \\
\hline
\end{tabular}

\section{d. Grafik}

Pada Gambar 3 dapat dilihat bahwa grafik penurunan rugi daya setelah di optimasi mengalami penurunan. Penurunan rugi-rugi daya saluran dari 0,5512
MVA hingga 5325 MVA. Dari generasi 0 hingga generasi 100 penurunan rugi-rugi daya saluran dari 0,5512 hingga 0,5342. Generasi 100 hingga generasi 1000 terjadi penurunan dari 0,5342 MVA hingga 0,5325 MVA. Maka dapat disimpulkan pengujian dengan $\mathrm{Pm}=0,5$ dan $\mathrm{Pc}=1$ dapat menurunkan rugi daya saluran hingga 0,5325 MVA.

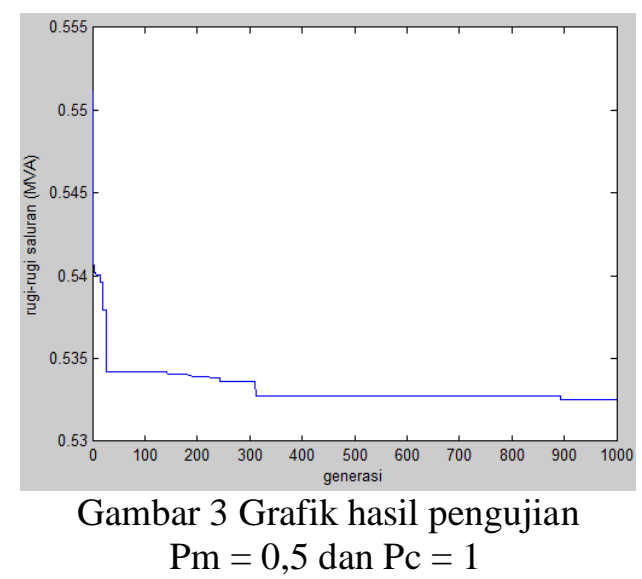

e. Grafik perbandingan hasil pengujian

1. Perbandigan faktor daya sebelum dan sesudah optimasi

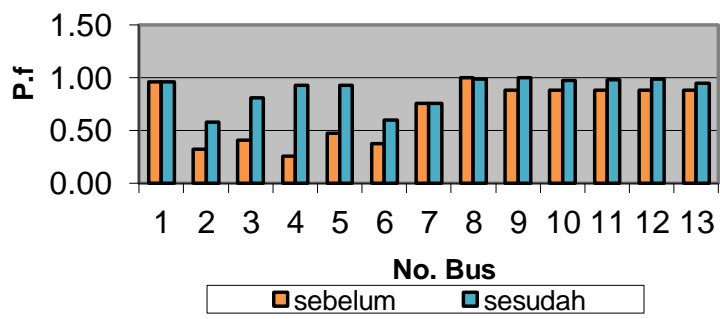

Gambar 4 Perbandingan faktor daya sebelum dan sesudah optimasi

Pada Gambar 4 dapat dilihat perbandingan faktor daya sebelum dan sesudah optimasi. Untuk faktor daya terdapat 13 bus, 9 bus mengalami kenaikan faktor daya. untuk bus nomor 1 dan 7 tidak mengalami perubahan sedangkan untuk bus nomor 8 mengalami penurunan faktor daya dari 0,998 menjadi 0,987

\section{Perbandingan tegangan bus sebelum dan sesudah optimasi \\ Pada Gambar 5 dapat dilihat perbandingan profil} tegangan bus sebelum dan sesudah optimasi. Untuk tegangan bus dari bus 1 sampai bus 8 dan bus 10 tidak mengalami perubahan. Untuk bus 9, 11,12 dan 13 mengalami peningkatan tegangan pada bus. 


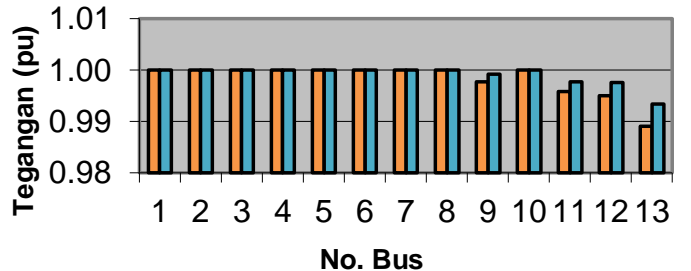

口sebelum 口sesudah

Gambar 5 Perbandingan profil tegangan bus sebelum dan sesudah optimasi

\section{Perbandingan rugi -rugi daya aktif sebelum dan sesudah optimasi}

Pada Gambar 6 dapat dilihat perbandingan rugi-rugi daya aktif sebelum dan sesudah optimasi. Perubahan penurunan rugi - rugi daya paling besar terjadi pada saluran nomor 9 dengan jumlah penurunan rugi-rugi daya saluran sebesar $6 \mathrm{~kW}$. Untuk penurunan rugi daya paling kecil yaitu $1 \mathrm{~kW}$ dapat dilihat pada saluran nomor 7 dan 12.

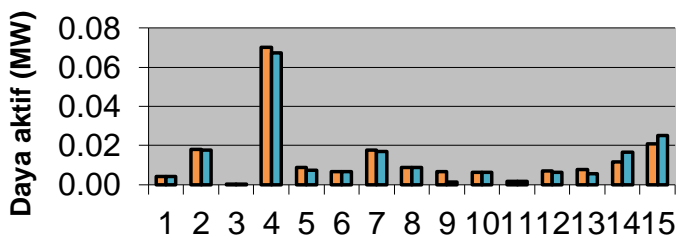

Saluran transmisi

口sebelum 口sesudah

Gambar 6 Perbandingan rugi-rugi daya aktif sebelum dan sesudah optimasi

\section{Perbandingan rugi-rugi daya reaktif sebelum dan sesudah optimasi}

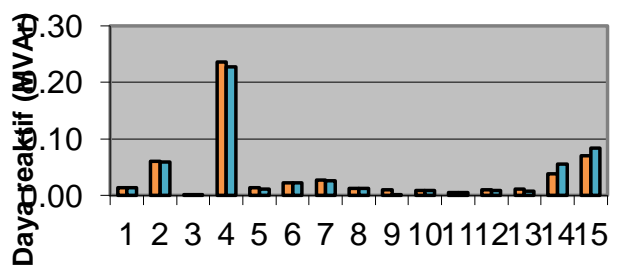

Saluran transmisi

口sebelum 口sesudah

Gambar 7. Perbandingan rugi-rugi daya reaktif sebelum dan sesudah optimasi

Pada Gambar 7 dapat dilihat perbandingan rugi-rugi daya reaktif sebelum dan sesudah optimasi. Perubahan penurunan rugi - rugi daya paling besar terjadi pada saluran nomor 4 dengan jumlah penurunan rugi-rugi daya salura sebesar $9 \mathrm{kVAr}$. Untuk penurunan rugi daya paling kecil yaitu $1 \mathrm{kVAr}$ dapat dilihat pada saluran nomor 7 dan 12.

\subsection{Perbandingan hasil setiap pengujian}

Pada tabel 4.4 Perbandingan total rugi daya saluran antar bus pada setiap pengujian dengan injeksi kapasitor 1-5 dan 1-7 MVAr

Tabel 5 Perbandingan hasil rugi daya setiap pengujian

\begin{tabular}{|c|c|c|c|c|c|c|c|c|c|}
\hline \multicolumn{9}{|c|}{ A. Injeksi kapasitor 1-5 MVAr } & \multirow{4}{*}{$\begin{array}{l}\text { Total } \\
\text { Injeksi } \\
\text { MVAr }\end{array}$} \\
\hline \multirow{3}{*}{ No. } & \multicolumn{8}{|c|}{ Rugi-rugi daya saluran } & \\
\hline & \multicolumn{2}{|c|}{ MW } & \multicolumn{2}{|c|}{ Penurunan } & \multicolumn{2}{|c|}{ MVAr } & \multicolumn{2}{|c|}{ Penurunan } & \\
\hline & Sebelum & Sesudah & MW & $\%$ & Sebelum & Sesudah & MVAr & $\%$ & \\
\hline 1. & 0,195 & 0,178 & 0,017 & 8,71 & 0,543 & 0,505 & 0,038 & 6,99 & 26,90 \\
\hline 2. & 0,195 & 0,178 & 0,017 & 8,71 & 0,543 & 0,505 & 0,038 & 6,99 & 29,88 \\
\hline 3. & 0,195 & 0,178 & 0,017 & 8,71 & 0,543 & 0,505 & 0,038 & 6,99 & 25,92 \\
\hline 4. & 0,195 & 0,178 & 0,017 & 8,71 & 0,543 & 0,506 & 0,038 & 6,99 & 23,93 \\
\hline \multicolumn{9}{|c|}{ B. Injeksi kapasitor 1-7 MVAr } & \\
\hline 1. & 0,195 & 0,177 & 0,018 & 9,23 & 0,543 & 0,502 & 0,041 & 7,55 & 38,90 \\
\hline 2. & 0,195 & 0,177 & 0,018 & 9,23 & 0,543 & 0,503 & 0,040 & 7,36 & 28,93 \\
\hline 3. & 0,195 & 0,177 & 0,018 & 9,23 & 0,543 & 0,502 & 0,041 & 7,55 & 40,91 \\
\hline 4. & 0,195 & 0,177 & 0,018 & 9,23 & 0,543 & 0,502 & 0,041 & 7,55 & 27,93 \\
\hline
\end{tabular}

Pada tabel 5 dapat dilihat bahwa pengujian yang dapat mereduksi rugi daya yang paling minimum adalah pengujian satu,tiga,dan empat pada injeksi 1-7 MVAr. Berdasarkan kriteria rugi daya yang minimum ketiga pengujian tersebut akan dipilih namun hasil dari penelitian di inginkan satu pengujian sebagai hasil maka dipilih pengujian dengan kriteria injeksi daya reaktif yang minimum. Injeksi rugi daya reaktif yang minimum terdapat pada pengujian empat, maka pengujian empat injeksi daya reaktif 1-7 MVAr dipilih sebagai hasil akhir.

Pengujian empat bagian B injeksi daya reaktif 1-7 MVAr memiliki rugi daya setelah optimasi sebesar 0,543 MW dan 0,502 MVAr. Untuk total injeksi daya reaktif pada pengujian satu sebesar 27,93 MVAr. Rugi daya saluran yang direduksi sebesar 0,018 MW atau 9,23\% dan 0,041 MVAr atau sebesar 7,55\%.

\subsection{Perbandingan hasil percobaan aliran daya matlab dan etap}

1. Running aliran daya sebelum optimasi pada etap Untuk running aliran daya pada etap sebelum optimasi dapat dilihat pada Gambar 8

Tabel 6 Perbandingan aliran daya pada matlab dan Etap sebelum optimasi

\begin{tabular}{|c|c|c|c|c|c|c|c|c|}
\hline \multirow[t]{2}{*}{$\begin{array}{l}\text { No. } \\
\text { Bus }\end{array}$} & \multicolumn{2}{|c|}{$\begin{array}{c}\text { Pembangkitan } \\
\text { Daya Aktif (MW) }\end{array}$} & \multicolumn{2}{|c|}{$\begin{array}{c}\begin{array}{c}\text { Pembangkitan } \\
\text { Daya Reaktif } \\
\text { (MVAr) }\end{array} \\
\end{array}$} & \multicolumn{2}{|c|}{ Tegangan (pu) } & \multicolumn{2}{|c|}{ Sudut $\left({ }^{\circ}\right)$} \\
\hline & Matlab & ETAP & Matlab & ETAP & Matlab & ETAP & Matlab & ETAP \\
\hline 1 & 27,89 & 27,911 & $-8,27$ & $-2,803$ & 1,000 & 1,000 & 0,000 & 0,000 \\
\hline \multirow[t]{2}{*}{$\begin{array}{l}\text { No. } \\
\text { Bus }\end{array}$} & \multicolumn{2}{|c|}{$\begin{array}{c}\text { Pembangkitan } \\
\text { Daya Aktif (MW) }\end{array}$} & \multicolumn{2}{|c|}{$\begin{array}{c}\text { Pembangkitan } \\
\text { Daya Reaktif } \\
\text { (MVAr) }\end{array}$} & \multicolumn{2}{|c|}{ Tegangan (pu) } & \multicolumn{2}{|c|}{ Sudut $\left({ }^{\circ}\right)$} \\
\hline & Matlab & ETAP & Matlab & ETAP & Matlab & ETAP & Matlab & ETAP \\
\hline 2 & 7,80 & 7,80 & 22,66 & 20,121 & 1,000 & 0,998 & $-0,028$ & 0,000 \\
\hline 3 & 18,10 & 18,10 & 15,51 & 11,217 & 1,000 & 0,995 & $-0,363$ & $-0,5$ \\
\hline 4 & 2,20 & 2,20 & 2,37 & 1,363 & 1,000 & 0,994 & $-0,746$ & $-0,7$ \\
\hline$\frac{4}{5}$ & $\frac{2,20}{6,20}$ & 6,20 & 4,56 & 3,842 & $\frac{1,000}{1,000}$ & 0,994 & $\begin{array}{l}0,990 \\
-0,992\end{array}$ & $-0,8$ \\
\hline 6 & 4,47 & 4,47 & 6,21 & 2,770 & 1,000 & 0,997 & $-0,327$ & 0,0 \\
\hline 7 & 8,60 & 8,60 & 1,91 & 2,701 & 1,000 & 1,000 & $-0,029$ & 0,4 \\
\hline 8 & 28,60 & 28,60 & $-1,76$ & 11,510 & 1,000 & 1,000 & $-0,016$ & 0,0 \\
\hline 9 & 0,00 & $\begin{array}{l}2,0,00 \\
0,00\end{array}$ & 0,00 & 0,00 & 0,998 & 0,992 & $-0,424$ & $-0,5$ \\
\hline 10 & 0,00 & 0,00 & 0,00 & 0,00 & 1,000 & 0,999 & $-0,026$ & 0,0 \\
\hline 11 & 0,00 & 0,00 & 0,00 & 0,00 & 0,996 & 0,997 & $-0,434$ & $-0,2$ \\
\hline 12 & 0,00 & 0,00 & 0,00 & 0,00 & 0,995 & 0,990 & $-0,947$ & $-0,8$ \\
\hline 13 & 0,00 & 0,00 & 0,00 & 0,00 & 0,989 & 0,982 & $-1,117$ & $-1,3$ \\
\hline
\end{tabular}




\begin{tabular}{|c|c|c|c|c|c|c|c|c|}
\hline \multirow{2}{*}{$\begin{array}{l}\text { No. } \\
\text { Bus }\end{array}$} & \multicolumn{2}{|c|}{$\begin{array}{c}\begin{array}{c}\text { Pembangkitan P } \\
\text { (MW) }\end{array} \\
\end{array}$} & \multicolumn{2}{|c|}{$\begin{array}{c}\text { Pembangkitan Q } \\
\text { (MVAr) }\end{array}$} & \multicolumn{2}{|c|}{ Tegangan (pu) } & \multicolumn{2}{|c|}{ Sudut $\left({ }^{\circ}\right)$} \\
\hline & Matlab & $\begin{array}{c}\text { ETA } \\
\text { P }\end{array}$ & Matlab & ETAP & Matlab & ETAP & Matlab & $\begin{array}{c}\text { ETA } \\
\text { P }\end{array}$ \\
\hline 1 & 27,87 & $\begin{array}{c}28,2 \\
3\end{array}$ & $-8,26$ & $-8,36$ & 1,000 & 1,000 & 0,000 & $\begin{array}{l}0,0 \\
00 \\
\end{array}$ \\
\hline 2 & 7,80 & 7,80 & 8,02 & 11,03 & 1,000 & 1,000 & $-0,028$ & $\begin{array}{c}0,0 \\
00\end{array}$ \\
\hline 3 & 18,10 & $\begin{array}{c}18,1 \\
0\end{array}$ & 10,24 & 11,03 & 1,000 & 1,000 & $-0,359$ & $-0,6$ \\
\hline 4 & 2,20 & 2,20 & 1,10 & 1,36 & 1,000 & 0,999 & $-0,723$ & $-0,8$ \\
\hline 5 & 6,20 & 6,20 & 3,15 & 3,18 & 1,000 & 1,000 & $-0,952$ & $-0,8$ \\
\hline 6 & 4,47 & 4,47 & 3,75 & 2,77 & 1,000 & 0,998 & $-0,307$ & $-0,1$ \\
\hline 7 & 8,60 & 8,60 & 1,91 & 1,54 & 1,000 & 1,000 & $\begin{array}{l}-0,009 \\
\end{array}$ & $-0,7$ \\
\hline 8 & 28,60 & $\begin{array}{c}28,6 \\
0 \\
\end{array}$ & $-4,71$ & 0,0 & 1,000 & 1,000 & $-0,016$ & 0,0 \\
\hline 9 & 0,00 & 0,00 & 0,00 & 0,00 & $\begin{array}{l}0,999 \\
\end{array}$ & 1,000 & $-0,444$ & $-0,7$ \\
\hline 10 & 0,00 & 0,00 & 0,00 & 0,00 & 1,000 & 1,000 & $-0,027$ & 0,0 \\
\hline 11 & 0,00 & 0,00 & 0,00 & 0,00 & 0,998 & 0,998 & $-0,468$ & $-0,2$ \\
\hline 12 & 0,00 & 0,00 & 0,00 & 0,00 & 0,998 & 0,996 & $-1,001$ & $-0,9$ \\
\hline 13 & 0,00 & 0,00 & 0,00 & 0,00 & 0,993 & 0,987 & $-1,188$ & $-1,4$ \\
\hline
\end{tabular}

Pada tabel 6 dapat dilihat hasil perbandingan aliran daya antara matlab dengan etap. Aliran daya yang dibandingkan seperti pembangkitan daya aktif dan daya reaktif, magnitude tegangan dan sudut tegangan.

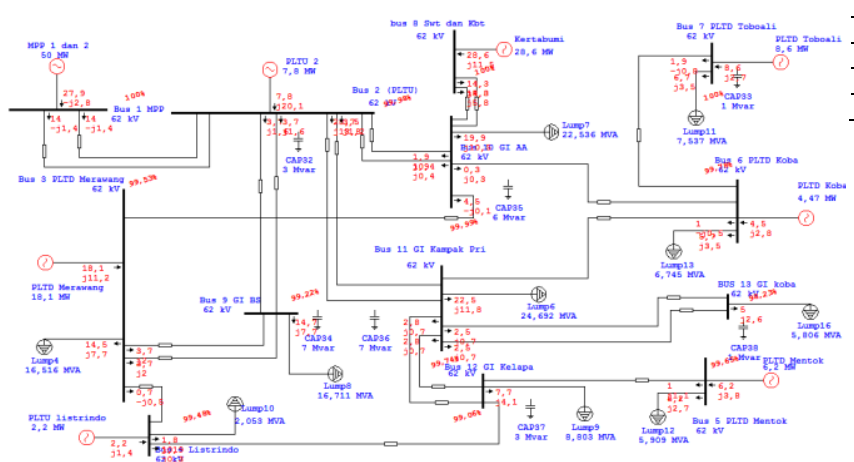

Gambar 8 Hasil running aliran daya sebelum optimasi

\section{Hasil running aliran daya setelah penambahan kapasitor}

Untuk penambahan kapasitor pada aliran daya setelah optimasi di pilih pengujian satu pada injeksi 1-7 MVAr. Total injeksi daya reaktif yang diperoleh dari optimasi pada pengujian B bagian empat sebesar 27,93 MVAr.

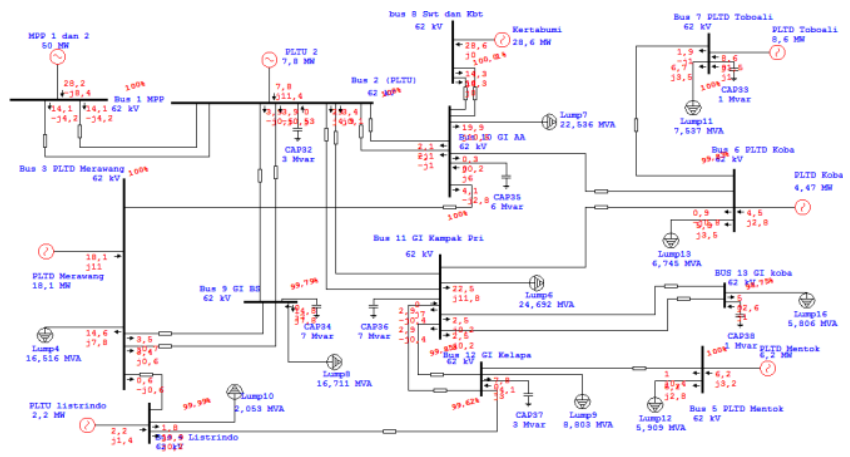

Gambar 9 Hasil running aliran daya setelah ditambah kapasitor dengan optimasi penempatan lokasi kapasitor dan nilai kapasitor dengan algoritma genetika.
Pada Gambar 9 merupakan hasil running aliran daya dengan menambahkan kapasitor yang telah di pilih lokasi dan nilainya dengan menggunakan algoritma genetika. Penempatan kapasitor yang didapat adalah pada bus $2=$ 3 MVAr, bus $6=1 \mathrm{MVAr}$, bus $9=7 \mathrm{MVAr}$, bus $10=6$ MVAr, bus $11=7$ MVAr, bus $12=3 \mathrm{MVAr}$, bus $13=1$ MVAr. Perbandingan aliran daya antara program matlab dan etap sesudah dioptimasi dapat dilihat pada tabel 4.6.

Tabel 7 Perbandingan aliran daya pada matlab dan etap sebelum optimasi

\begin{tabular}{ccccccccc}
\hline \multirow{2}{*}{$\begin{array}{c}\text { No. } \\
\text { Bus }\end{array}$} & \multicolumn{9}{c}{$\begin{array}{c}\text { Pembangkitan P } \\
\text { (MW) }\end{array}$} & \multicolumn{2}{c}{$\begin{array}{c}\text { Pembangkitan Q } \\
\text { (MVAr) }\end{array}$} & \multicolumn{2}{c}{ Tegangan (pu) } & \multicolumn{2}{c}{ Sudut $\left({ }^{\circ}\right)$} \\
\cline { 2 - 9 } & Matlab & ETAP & Matlab & ETAP & Matlab & ETAP & Matlab & ETAP \\
\hline 1 & 27,87 & 28,23 & $-8,26$ & $-8,36$ & 1,000 & 1,000 & 0,000 & 0,000 \\
\hline 2 & 7,80 & 7,80 & 8,02 & 11,03 & 1,000 & 1,000 & $-0,028$ & 0,000 \\
\hline 3 & 18,10 & 18,10 & 10,24 & 11,03 & 1,000 & 1,000 & $-0,359$ & $-0,6$ \\
\hline 4 & 2,20 & 2,20 & 1,10 & 1,36 & 1,000 & 0,999 & $-0,723$ & $-0,8$ \\
\hline 5 & 6,20 & 6,20 & 3,15 & 3,18 & 1,000 & 1,000 & $-0,952$ & $-0,8$ \\
\hline 6 & 4,47 & 4,47 & 3,75 & 2,77 & 1,000 & 0,998 & $-0,307$ & $-0,1$ \\
\hline 7 & 8,60 & 8,60 & 1,91 & 1,54 & 1,000 & 1,000 & $-0,009$ & $-0,7$ \\
\hline 8 & 28,60 & 28,60 & $-4,71$ & 0,0 & 1,000 & 1,000 & $-0,016$ & 0,0 \\
\hline 9 & 0,00 & 0,00 & 0,00 & 0,00 & 0,999 & 1,000 & $-0,444$ & $-0,7$ \\
\hline 10 & 0,00 & 0,00 & 0,00 & 0,00 & 1,000 & 1,000 & $-0,027$ & 0,0 \\
\hline 11 & 0,00 & 0,00 & 0,00 & 0,00 & 0,998 & 0,998 & $-0,468$ & $-0,2$ \\
\hline 12 & 0,00 & 0,00 & 0,00 & 0,00 & 0,998 & 0,996 & $-1,001$ & $-0,9$ \\
\hline 13 & 0,00 & 0,00 & 0,00 & 0,00 & 0,993 & 0,987 & $-1,188$ & $-1,4$ \\
\hline
\end{tabular}

Untuk rugi-rugi daya saluran yang akan dibandingkan adalah rugi-rugi daya saluran pada pengujian satu yang terpilih yaitu pengujian dengan injeksi 1-5 MVAr. Pada tabel 8 dan tabel 9 dapat dilihat hasil perbandingan rugi-rugi daya saluran pada matlab dan etap sebelum dan sesudah optimasi

Tabel 8 Hasil rugi-rugi daya saluran pada matlab dan etap sebelum penambahan kapasitor

\begin{tabular}{ccccccc}
\hline \multirow{2}{*}{ No. } & Dari & \multirow{2}{*}{ Ke } & \multicolumn{2}{c}{ Aktif (MW) } & \multicolumn{2}{c}{ Reaktif (MVAr) } \\
\cline { 5 - 7 } & Bus & Bus & Matlab & Etap & Matlab & Etap \\
\hline 1 & 1 & 2 & 0,004 & 0,007 & 0,014 & 0,013 \\
\hline 2 & 2 & 9 & 0,018 & 0,027 & 0,061 & $-0,331$ \\
\hline 3 & 2 & 10 & 0,000 & 0,000 & 0,000 & $-0,002$ \\
\hline 4 & 2 & 11 & 0,070 & 0,039 & 0,236 & 0,022 \\
\hline 5 & 3 & 4 & 0,009 & 0,002 & 0,013 & $-0,449$ \\
\hline 6 & 3 & 9 & 0,007 & 0,017 & 0,022 & $-0,132$ \\
\hline 7 & 3 & 10 & 0,018 & 0,021 & 0,027 & $-0,142$ \\
\hline 8 & 4 & 12 & 0,009 & 0,003 & 0,013 & $-0,378$ \\
\hline 9 & 5 & 12 & 0,007 & 0,005 & 0,010 & $-0,338$ \\
\hline 10 & 6 & 7 & 0,006 & 0,009 & 0,010 & $-0,374$ \\
\hline 11 & 8 & 10 & 0,002 & 0,002 & 0,005 & 0,004 \\
\hline 12 & 10 & 6 & 0,007 & 0,001 & 0,011 & $-0,355$ \\
\hline 13 & 11 & 6 & 0,008 & 0,002 & 0,012 & $-0,245$ \\
\hline 14 & 11 & 12 & 0,012 & 0,021 & 0,039 & $-0,542$ \\
\hline 15 & 11 & 13 & 0,021 & 0,037 & 0,070 & $-1,153$ \\
\hline
\end{tabular}


Tabel 9 Hasil rugi-rugi daya saluran pada matlab dan Etap setelah penambahan kapasitor

\begin{tabular}{|c|c|c|c|c|c|c|}
\hline \multirow[b]{2}{*}{ No. } & \multirow{2}{*}{$\begin{array}{l}\text { Dari } \\
\text { Bus }\end{array}$} & \multirow{2}{*}{$\begin{array}{l}\text { Ke } \\
\text { Bus }\end{array}$} & \multicolumn{2}{|c|}{ Aktif (MW) } & \multicolumn{2}{|c|}{ Reaktif (MVAr) } \\
\hline & & & Matlab & Etap & Matlab & Etap \\
\hline 1 & 1 & 2 & 0,004 & 0,007 & 0,014 & 0,0157 \\
\hline 2 & 2 & 9 & 0,018 & 0,025 & 0,059 & $-0,338$ \\
\hline 3 & 2 & 10 & 0,000 & 0,0005 & 0,000 & $-0,002$ \\
\hline 4 & 2 & 11 & 0,067 & 0,033 & 0,227 & 0,0035 \\
\hline 5 & 3 & 4 & 0,007 & 0,002 & 0,011 & $-0,453$ \\
\hline \multirow[b]{2}{*}{ No. } & \multirow{2}{*}{$\begin{array}{c}\text { Dari } \\
\text { Bus }\end{array}$} & \multirow{2}{*}{$\begin{array}{l}\text { Ke } \\
\text { Bus }\end{array}$} & \multicolumn{2}{|c|}{ Aktif (MW) } & \multicolumn{2}{|c|}{ Reaktif (MVAr) } \\
\hline & & & Matlab & Etap & Matlab & Etap \\
\hline 6 & 3 & 9 & 0,007 & 0,012 & 0,022 & $-0,142$ \\
\hline 7 & 3 & 10 & 0,017 & 0,024 & 0,026 & $-0,138$ \\
\hline 8 & 4 & 12 & 0,009 & 0,003 & 0,013 & $-0,383$ \\
\hline 9 & 5 & 12 & 0,001 & 0,003 & 0,002 & $-0,345$ \\
\hline 10 & 6 & 7 & 0,006 & 0,01 & 0,010 & $-0,374$ \\
\hline 11 & 8 & 10 & 0,002 & 0,002 & 0,005 & 0,0036 \\
\hline 12 & 10 & 6 & 0,006 & 0,0004 & 0,010 & $-0,356$ \\
\hline 13 & 11 & 6 & 0,005 & 0,002 & 0,008 & $-0,245$ \\
\hline 14 & 11 & 12 & 0,017 & 0,02 & 0,056 & $-0,549$ \\
\hline 15 & 11 & 13 & 0,025 & 0,034 & 0,084 & $-1,172$ \\
\hline
\end{tabular}

\section{PENUTUP}

\subsection{Kesimpulan}

1. Pada pengujian aliran daya sebelum optimasi diperoleh rugi-rugi daya saluran pada sistem kelistrikan area Bangka sebesar 0,195 MW dan 0,543 MVAr atau $195 \mathrm{~kW}$ dan $543 \mathrm{kVAr}$, sedangkan rugi daya sesudah optimasi pada pengujian terpilih yaitu sebesar $0,177 \mathrm{MW}$ dan 0,502 MVAr atau $177 \mathrm{~kW}$ dan $502 \mathrm{kVAr}$.

2. Pada pengujian empat dengan injeksi kapasitor 1-7 MVAr memiliki penurunan rugi daya sebesar 0,018 MW dan 0,041 MVAr. Persentase penurunan rugi-rugi daya saluran sebesar $9,23 \%$ untuk daya aktif dan 7,55\% untuk daya reaktif.

3. Parameter algoritma genetika yang tepat dalam optimasi daya reaktif adalah $\mathrm{Pc}=1 \mathrm{Pm}=0,5$ dengan injeksi kapasitor 1-7 MVAr dengan generasi maksimal 1000.

4. Total injeksi daya reaktif yang didapatkan pada pengujian yang dipilih sebesar 27,93 MVAr. Penempatan kapasitor yang didapat adalah pada bus $2=3$ MVAr, bus $6=1$ MVAr, bus $9=7$ MVAr, bus $10=6 \mathrm{MVAr}$, bus $11=7 \mathrm{MVAr}$, bus $12=3$ MVAr, bus $13=1$ MVAr.

\subsection{Saran}

1. Pada perbandingan aliran daya antara matlab dan etap masih memiliki perbedaan nilai yang cukup besar untuk penyediaan daya reaktif pada bus generator. Untuk penelitian selanjutnya disarankan memperhatikan aliran daya pada matlab.

2. Metode optimasi daya reaktif yang digunakan berdasarkan teori pada buku imam robandi tentang injeksi daya reaktif halaman 309. Untuk penelitian selanjutnya tentang optimasi daya reaktif disarankan menggunakan teori pada buku imam robandi dengan subtema penempatan, penggantian dan penentuan ukuran kapasitor bank yang optimal.

3. Pengujian yang telah dilakukan perhitungan optimasi hanya menggunakan variasi nilai probabilitas mutasi dan probabilitas crossover. Untuk selanjutnya bisa memperhitungan jumlah kromosom atau perubahan letak kapasitor.

4. Untuk memperoleh pencapaian pembangkitan dan penyaluran sistem tenaga yang ekonomis disarankan menggunakan metode pemilihan dan penempatan peralatan FACTS ( Flexible AC Transmision System) yang optimal dengan menggunakan Algoritma genetika.

\section{DAFTAR PUSTAKA}

[1] Fahlevi, Reza., 2013, Optimasi daya reaktif untuk mereduksi rugi daya pada sistem JAMALI $500 \mathrm{kV}$ menggunakan metode algoritma genetika, Jurnal Transient, Vol.2,No. 3, September 2013, ISSN : 2302-9927, 559.

[2] Fahri,Khoirul., 2016, Analisis Aliran Daya pada Sistem Tenaga Listrik PLN Area Bangka, Tugas akhir Jurusan Teknik Elektro Universitas Bangka Belitung

[3] Firmansyah SB,Rizki dan Liun,Edwaren,2012, Aplikasi Algoritma Genetik Untuk Perbaikan Tegangan Saluran 20kv Di Sekitar Wilayah PLTN,Lokakarya Komputasi dalam Sains dan Teknologi Nuklir,10 Oktober 2012 (535-366)

[4] Kusumadewi,Sri dan Purnomo,Hari., 2005 Penyelesaian Masalah Optimasi Dengan Teknikteknik Heuristik, Graha Ilmu, Yogyakarta.

[5] Laksono,Heru Dibyo.,2010,Optimasi Penempatan Kapasitor Pada Sistem Tenaga Listrik Dengan Menggunakan Algorima Genetikab (Studi Kasus Sistem PT.PLN Sumbar-Riau).No.34 Vol.Thn.XVII November 2010,ISSN:0845-8471

[6] Marsudi,Djiteng.,2006, Operasi Sistem Tenaga Listrik, Graha Ilmu, Yogyakarta.

[7] Marsudi,Djiteng., 2005 , Pembangkitan Energi Listrik, Erlangga, Jakarta.

[8] Robandi,Imam.,2006,Desain Sistem Tenaga Modern, Andi,Yogyakarta

[9] Santosa,Budi., 2008, Matlab Untuk Sstatistika dan Teknik Optimasi, Graha Ilmu, Jogjakarta

[10] Suyanto., 2014, Artificial Intellingence, Informatika,Bandung

[11] Suyanto.,2005,Algoritma Genetika Dalam Matlab, Andi,Yogyakarta

[12] Stevenson,William D.Jr.,1983,Analisis Sistem Tenaga Listrik, Erlangga, Jakarta.

[13] Widodo,Prabowo Pudjo dan Handayanto, Rahmadya Trias, 2012, Penerapan Soft Computing Dengan Matlab, Rekayasa Sains, Bandung.

[14] Tobing,L Bonggas.,2003,Peralatan Tegangan Tinggi, Graha Ilmu, Yogyakarta

[15] Yunus,Syukri,dkk.,2016, Memperbaiki Tegangan dan Rugi-rugi Daya Pada Sistem Transmisi Dengan Optimasi Penempatan Kapasitor Menggunakan 
Algoritma Genetika, Vol.2,No.2,Juli 2016,ISSN :2302-2949.

[16] Zukhri, Zainudin.,2014, Algoritma Genetika Metode Komputasi Evolusioner untuk Menyelesaikan Masalah Optimasi, Andi, Yogyakarta

[17] .........1987, SPLN No.72 Tahun 1987 tentang batas profil tegangan saluran udara tegangan menengah tidak melebihi $5 \%$, SPLN.

[18] ........1983. Standar IEEE 60038 tahun 1983 profil tegangan bus berada pada range $+5 \%$.

${ }^{[19]}$. ........2017, Data Single line dan SUTM $20 \mathrm{kV}$ Kelistrikan Area Bangka, PT PLN (Persero) Area Bangka, Jl.Jend. Sudirman No.180 Selindung Baru Pangkalpinang.

[20] .......2017, Data Pembangkitan dan Pembebanan Bulan Maret 2017 dan Single line, Panjang saluran serta impedansi SUTT $150 \mathrm{kV}$ Kelistrikan Area Bangka, PT PLN (Persero) Wilayah Bangka Belitung Sektor Pembangkitan Desa Air Anyir,Kec.Merawang, Kabupaten Bangka 
